\title{
Pelatihan Mikrokontroler Dalam Pengenalan Robotika Sebagai Respon Revolusi Industri 4.0 Di SMK Media Informatika Dasana Indah Tengerang
}

\author{
Meyhart Bangkit S. ${ }^{1}$; Albert Gifson H. ${ }^{2}$; Juara M. T. ${ }^{3}$; Hastuti Azis. ${ }^{4}$ \\ 1, 2, 3,4 Institut Teknik PLN \\ ${ }^{1}$ bangkit@itpln.ac.id
}

\begin{abstract}
Industry 4.0 fundamentals involve at least 4 thing : interconnection (machines, devices and people are connected), information transparency (data analysis needs), decentralized decisions (effects of interconnection and information transparency) and technical assistance (the purpose of industry 4.0). Collaboration between machines / devices and humans is very important to implement Industry 4.0. In this collaboration, the role of the microcontroller as a connector between machines and humans. Microcontroller Training for Introduction of Robotics as a Response to the Revolution of Industry 4.0 at SMK Media Informatika Dasana Indah Tengerang is aimed for students and teacher so they know about Industry 4.0 and its application in microcontroller programming. Therefore the method of PKM program consists of seminar and workshop. The seminar explained about Industry 4.0 Revolution and the workshop is programming Line Follower which is embedded with Arduino Uno. Result of this PKM program in the form of industry 4.0 revolution seminar combine with microcontroller programming workshop, this combination give bigger impact compared with just given a seminar or just a workshop. The students and teacher who attend this event get additional knowledge about Industry 4.0 and how to program a microcontroller.
\end{abstract}

Keywords: PKM, Industry 4.0, Programming, Microcontroller, Arduino

\begin{abstract}
ABSTRAK
Dasar dari Industri 4.0 setidaknya melibatkan 4 hal, yaitu interkoneksi (mesin, perangkat dan manusia saling terhubung), transparansi informasi (untuk kebutuhan analisis data), keputusan terdesentralisasi (efek dari interkoneksi dan transparansi informasi mendukung dapat dilakukannya hal ini) dan bantuan teknis (tujuan dari dilakukannya industri 4.0). Kolaborasi antara mesin/perangkat dengan manusia sangat berperan penting dalam terciptanya Industri 4.0. Pada bagian inilah perannya mikrokontroler sebagai penghubung antar mesin dan manusia. Pelatihan Mikrokontroler Dalam Pengenalan Robotika Sebagai Respon Revolusi Industri 4.0 di SMK Media Informatika Dasana Indah Tengerang ini ditujukan pada para siswa-siswi dan guru agar mereka mengenal Industri 4.0 dan sedikit penerapannya pada pemrograman mikrokontorler. Sehingga metode pelaksanaan PKM yaitu dengan seminar dan pelatihan. Seminar berisi materi Revolusi Industri 4.0 yang diharapkan memberikan pemahaman mengenai perkembangan dunia industri sampai saat ini dan pelatihan pemrograman mikrokontroler dilakukan dengan peserta memprogram Line Follower yang ditanamkan Arduino. Hasil dari program PKM yang dibuat dalam bentuk seminar Revolusi Industri 4.0 dan dilanjutkan dengan pelatihan pemrograman Mikrokontroler didapatkan penggabungan kedua bahwa metode ini memberikan dampak lebih dibandingkan dengan hanya memberikan seminar atau pelatihan saja. Para siswa-siswi dan guru yang mengikuti kegiatan mendapatkan pengetahuan tambahan mengenai Industri 4.0 dan cara memprogram mikrokontroler.
\end{abstract}

Kata kunci: PKM, Indsutri 4.0, Pemrograman, Mikrokontroler, Arduino 


\section{PENDAHULUAN}

Teknologi dan informasi terus maju dan berkembang seiring dengan meningkatnya ilmu pengetahuan. Tuntutan kebutuhan mendorong manusia terus mengembangkan ide-ide baru demi memudahkan pekerjaan manusia. Dewasa ini ilmu pengetahuan (dalam arti artikel tentang ilmu pengetahuan) sangat mudah dijumpai, bahkan seringkali gratis dan dapat diakses lewat media elektronik. Hal ini juga yang menjadi pemicu cepatnya perubahan pada ilmu pengetahuan. Ilmu pengetahuan menjadi lebih up to date, dapat dikritik untuk pembenahan dan dipakai oleh berbagai kalangan masyarakat.

Hal tersebut bisa terjadi karena jaman ini berada pada era Industri 4.0. Era dimana hampir segala sesuatu terhubung dengan jaringan yang benama Internet. Komunikasi menjadi salah satu hal yang paling memanfaatkan teknologi ini karena menjadi lebih murah dan kebebasan fitur yang diberikan sangatlah fleksibel. Secara singkat era Industri 4.0 merupakan era penggunaan internet dalam memudahkan pekerjaan manusia.

Istilah Industri 4.0 sendiri mulai muncul dari Jerman dengan istilah "Industrie 4.0", yang seringkali dipahami sebagai penerapan sistem dunia maya (cyber) pada sistem produksi perindustrian[1]. Di Amerika mirip dengan istilah ini dikenal dengan istilah "Industrial Internet", namun seiring dengan terbitnya publikasi-publikasi mengenai hal ini maka istilah yang sering dipakai adalah Industri 4.0.

Dasar dari pembentukan Industri 4.0 setidaknya melibatkan 4 hal, yaitu interkoneksi (mesin, perangkat dan manusia saling terhubung), transparansi informasi (untuk kebutuhan analisis data), keputusan terdesentralisasi (efek dari interkoneksi dan transparansi informasi mendukung dapat dilakukannya hal ini) dan bantuan teknis (tujuan dari dilakukannya industri 4.0)[2]. Kolaborasi antara mesin/perangkat dengan manusia sangat berperan penting dalam terciptanya Industri 4.0. Pada bagian inilah pentingnya mikrokontroler sebagai penghubung antar mesin dan manusia.

Pelatihan mikrokontroler sebelumnya mendapatkan respon yang sangat positif dari para peserta pelatihan. Pelatihan dinilai memberi wawasan tambahan mengenai Industri 4.0 dan peserta menjadi tertarik untuk mendalami pemrograman [3]. Hal ini sangat baik sebab di dunia industri ke depan akan sangat membutuhkan kemampuan dalam hal komputer dan pemrograman. Sehingga dirasakan adalah perlu untuk membekali lagi pada generasi milenial saat ini.

Selain itu banyak juga pelatihan mikrokontroler lain yang sudah dilaksanakan dan semuanya mendapatkan respon yang sangat baik, pelatihan pada guru [4][5], siswa SMA/SMK [4] [5][6][7][8] dan bahkan alumni kampus [9]. Dari pelatihan-pelatihan yang dibuat kebanyakan peserta merupakan siswa-siswi SMA/SMK. Hal ini dikarenakan mereka dianggap mampu untuk memahami materi dan akan melanjutkan studi ke perguruan tinggi, sehingga pelatihan diharapkan memberikan dorongan untuk peserta mengambil jurusan di bidang Teknik ketika memilih jurusan saat kuliah.

Pelatihan Mikrokontroler Dalam Pengenalan Robotika Sebagai Respon Revolusi Industri 4.0 di SMK Media Informatika Dasana Indah Tengerang ini ditujukan pada para siswa-siswi. Yang membedakan dari pelatihan sebelum-sebelumnya adalah terdapat sesi seminar sebagai pengenalan Revolusi Industri 4.0. Seminar berisi materi Revolusi Industri 4.0 yang diharapkan memberikan pemahaman mengenai pentingnya pelatihan yang akan diberikan dan manfaat dari pelatihan.

Pelatihan dilaksanakan di hari berbeda dengan pelaksanaan seminar karena membutuhkan waktu yang lebih lama. Pelatihan menggunakan Line Follower yang diprogram menggunakan Arduino Uno[10] sebagai alat bantu untuk pemrograman. Peserta diberikan masing-masing sebuah Line Follower dan diijinkan untuk memprogram Line Follower agar bergerak mengikuti garis. Peserta berlomba memprogram dan menguji programnya. Peserta memprogram menggunakan laptop pribadi dan yang tercepat akan mendapatkan hadiah. 


\section{METODE PELAKSANAAN}

Pelaksanaan Pengabdian Kepada Masyarakat yang dilakukan yaitu berupa seminar dan pelatihan. Seminar ditujukan agar peserta memiliki pemahaman dasar mengenai teknologi yang berkembang dewasa ini. Pelatihan ditujukan agar peserta dibekali dengan ilmu dasar pemograman mikrokontroler sehingga dapat membuat sebuah perangkat melakukan tugas yang dikehendaki. dilakukan.

Bagan berikut menjelaskan alur pengerjaan program Pengabdian Kepada Masyarakat yang

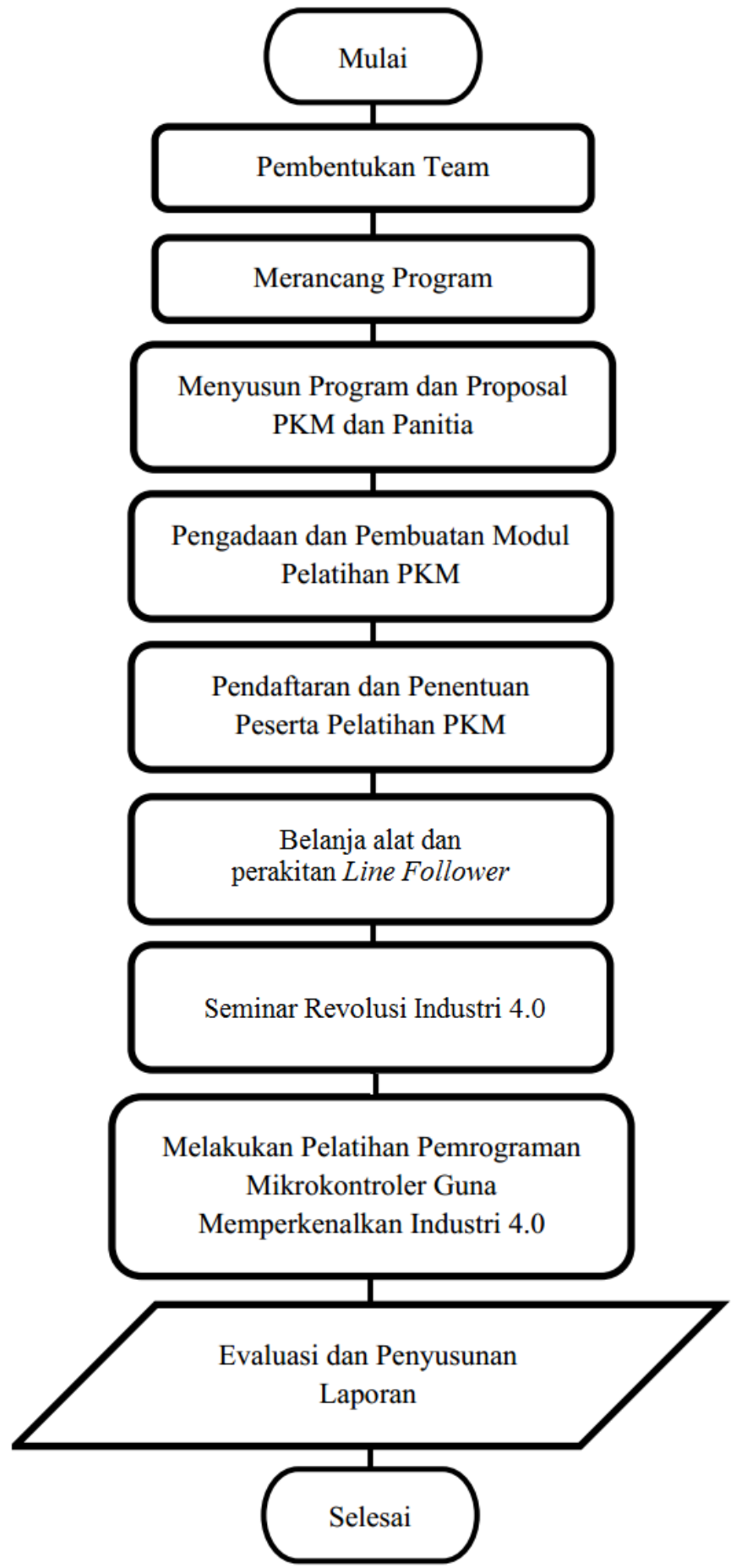

Gambar 1. Bagan alir pengerjaan program Pengabdian Kepada Masyarakat 
Tim PKM terdiri dari dosen dan mahasiswa. Dosen berperan sebagai penanggung jawab kegiatan, merancang program PKM dan membawakan seminar serta pelatihan. Mahasiswa berperan membantu dosen dalam perakitan alat Line Follower dan menemani siswa-siswi sebagai tutor pada saat pelatihan mikrokontroler diadakan.

Seminar dilakukan terlebih dahulu sebelum pelatihan. Seminar berisikan materi Revolusi Industri 4.0 dan pelatihan berisi pemaparan Robotika dan mengaplikasikan dengan memprogram mikrokontroler Arduino Uno yang sudah dirakit menjadi sebuah Line Follower. Seminar dilakukan di SMK Media Informatika Tangerang. Peserta boleh dari berbagai kejuruan yang tertarik untuk ikut serta, sebab materi diberikan ringkas dan mudah dimengerti. Sedangkan pelatihan ditujukan bagi siswa-siswi yang berjurusan di Teknik Komputer dan Jaringan.

Pelatihan berfokus untuk mengajarkan para peserta memprogram mikrokontroler dengan menggunakan aplikasi Arduino IDE sebagai aplikasi pemrogramannya. Pelatihan diawali dengan pengenalan robotika dan pemahaman mikrokontroler serta pengenalan Arduino Uno[10] yang disampaikan oleh tim dosen. Peserta mendapatkan modul hand out dan alat berupa Line Foolower yang sudah dibuat. Masing-masing peserta memegang satu alat. Peserta menggunakan laptop pribadi untuk melakukan pemrograman mikrokontrolernya. Pelatihan dibantu oleh mahasiswa agar mempermudah tugas tim dosen.

\section{HASIL DAN PEMBAHASAN}

\subsection{Perakitan Alat Line Follower}

Perakitan Line Follower dilakukan oleh asisten mahasiswa yang dikordinir oleh tim dosen. Alat yang dibuat adalah sebanyak 40 unit. Maksud dari perakitan ini agar mahasiswa belajar dan memahami terlebih dahulu mengenai alat yang akan dipakai sebagai peraga nantinya. Perakitan terdiri dari tiga tahap sebagai berikut :

- Tahap 1. Memasang roda dan tempat baterai pada chasis. Diperlukan lubang tambahan pada chasis untuk memasang Arduino dan tempat baterai, sehingga tahap ini cukup sulit. Sebaiknya chasis yang dipakai adalah rancangan sendiri, tetapi hal ini juga akan mempengaruhi biaya pembuatan nantinya.

- Tahap 2. Pemasangan bagian elektronika. Pada bagian ini dilakukan pemasangan Arduino, Driver Stepper Motor, sensor infra merah, kabel dan instalasi baterai. Setelah dirakit, dicoba untuk menajalankan Line Follower. Didapatkan bahwa rangkaian baru bisa bekerja jika diberikan tegangan sebesar 12 Volt DC, cukup boros karena motor yang dipakai adalah motor 3-6 Volt. Sehingga baterai yang dipakai adalah 8 buah batu baterai untuk menjalankan Line Follower. Penyebabnya adalah dari Driver Motor yang dipakai. Sebaiknya jika dibuat rangkaian driver motor sendiri menggunakan transistor logic agar sesuai dengan kebutuhan.

- Tahap 3. Memprogram mikrokontroler. Pada tahap ini tiap Line Follower yang sudah jadi dimasukkan program agar bisa membaca jalur yang diberikan. Arena dibuat dari kertas putih polos yang ditempel lakban hitam sebagai jalur. Tahapan ini untuk menguji masingmasing alat agar pada saat praktikan mencoba tidak bermasalah. Jika unit tidak bermasalah, maka lolos Quality Control lalu Arduino dikosongkan kembali. 

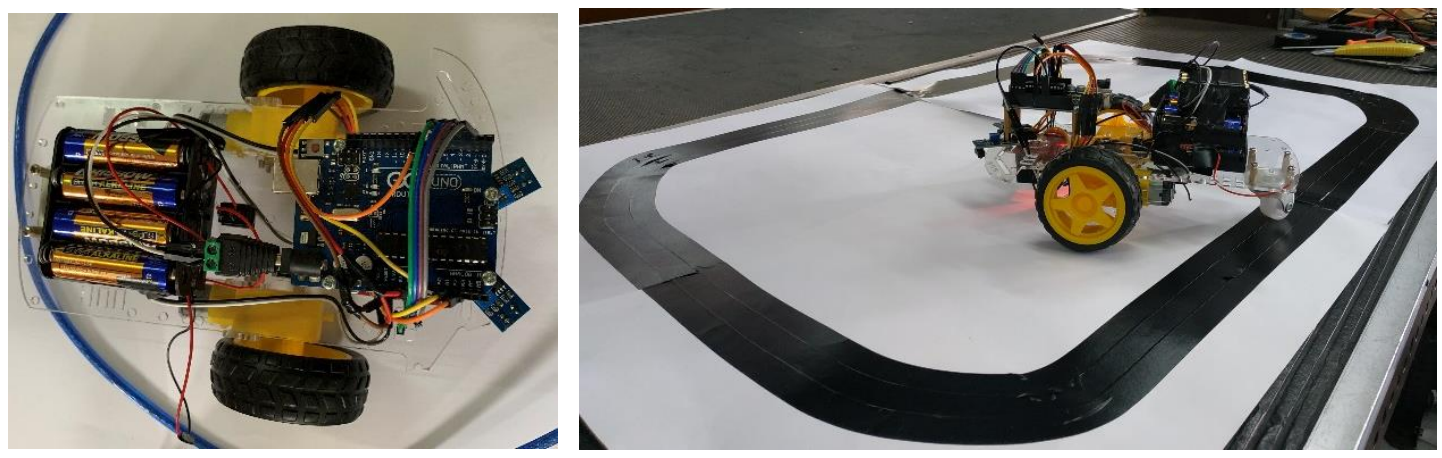

Gambar 2. Line Follower dan Arenanya

\subsection{Pelaksanaan Seminar}

Pelaksanaan Seminar Revolusi Industri 4.0 diadakan di SMK Media Informatika pada tanggal 22 Januari 2020[11]. Seminar dibuka oleh kepala sekolah SMK Media Informatika dan materi dibawakan oleh tim dosen. Seminar diikuti oleh orang siswa-siswi dan guru SMK Media Informatika.

Seminar berisikan pengertian Industri 4.0 dan bagaimana Revolusi industri dari 1.0 ke 4.0. Kemudian bagaimana wajah kegiatan ekonomi saat ini dimana hampir semua pekerjaan sudah menggunakan internet dan teknologi digital. Kemudian ditunjukan juga perubahan apa yang terjadi di Indonesia seperti took fisik yang menjadi toko online dan transportasi konvensional (ojek dan taksi) sudah dimudahkan dengan aplikasi online. Dipaparkan juga keterampilan apa saja yang dibutuhkan untuk bisa bersaing di masa mendatang serta lowongan pekerjaan apa saja yang akan tersedia dan akan hilang di masa mendatang.

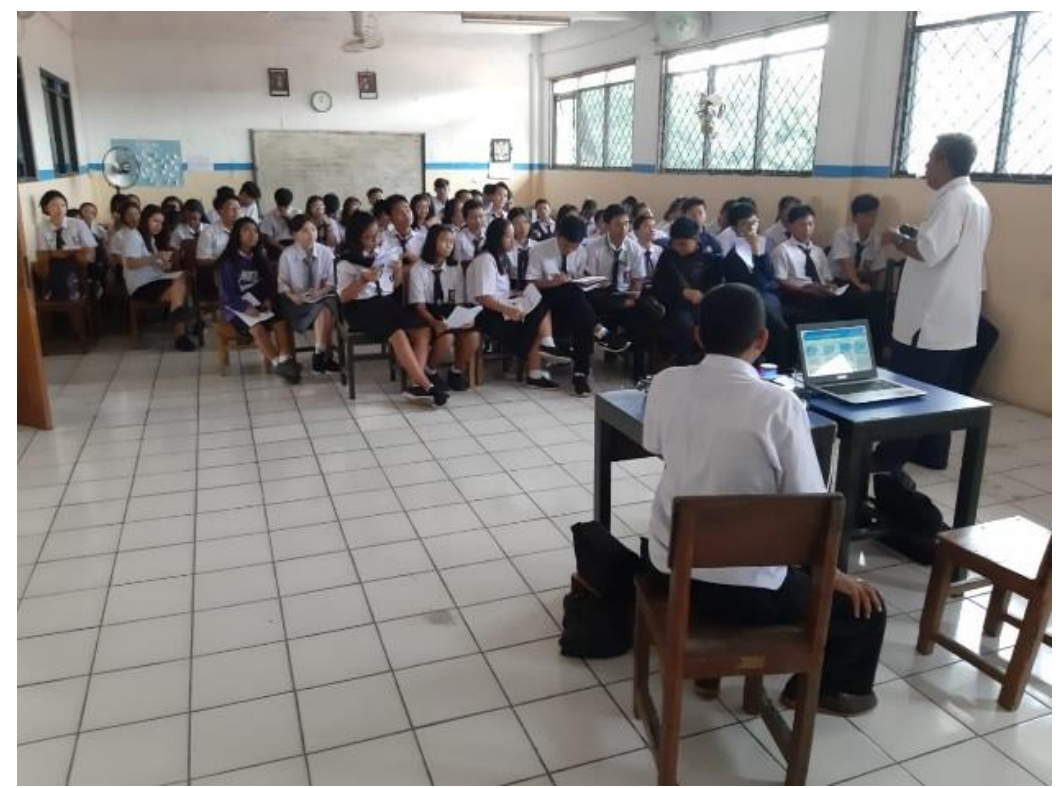

Gambar 3. Pelaksanaan Seminar Revolusi Industri 4.0

\subsection{Pelaksanaan Pelatihan Mikrokontroler}

Pelaksanaan pelatihan mikrokontroler dilakukan pada tanggal 17 Februari 2020 dengan memanfaatkan ruangan Laboratorium Komputer SMK Media Informatika[11]. Pelatihan dibuka oleh kepala sekolah SMK Media Informatika dan dilanjutkan oleh materi pelatihan dari tim dosen. Peserta merupakan siswa dari jurusan Teknik Komputer dan Jaringan serta guru TIK. Peserta membawa laptop pribadi untuk memprogram mikrokontroler. 
Pelatihan dimulai dengan pengenalan mengenai robotika dan manfaat mikrokontroler. Laptop peserta dipasang dahulu aplikasi Arduino IDE yang akan dipakai untuk memprogram Arduino. Kemudian peserta dibagikan hand out dan alat praktikum berupa Line Follower yang sudah dibuat, masing-masing peserta memegang satu alat agar bisa mencoba sendiri. Kemudian menggunakan aplikasi Arduino IDE peserta memprogram Line Follower yang dibagikan sesuai dengan kode program yang diberikan di handout. Agar lebih menarik diberikan hadiah untuk peserta pertama dan kedua yang lebih dahulu berhasil memprogram Line Follower agar bisa jalan pada arena sulit yang diberikan.
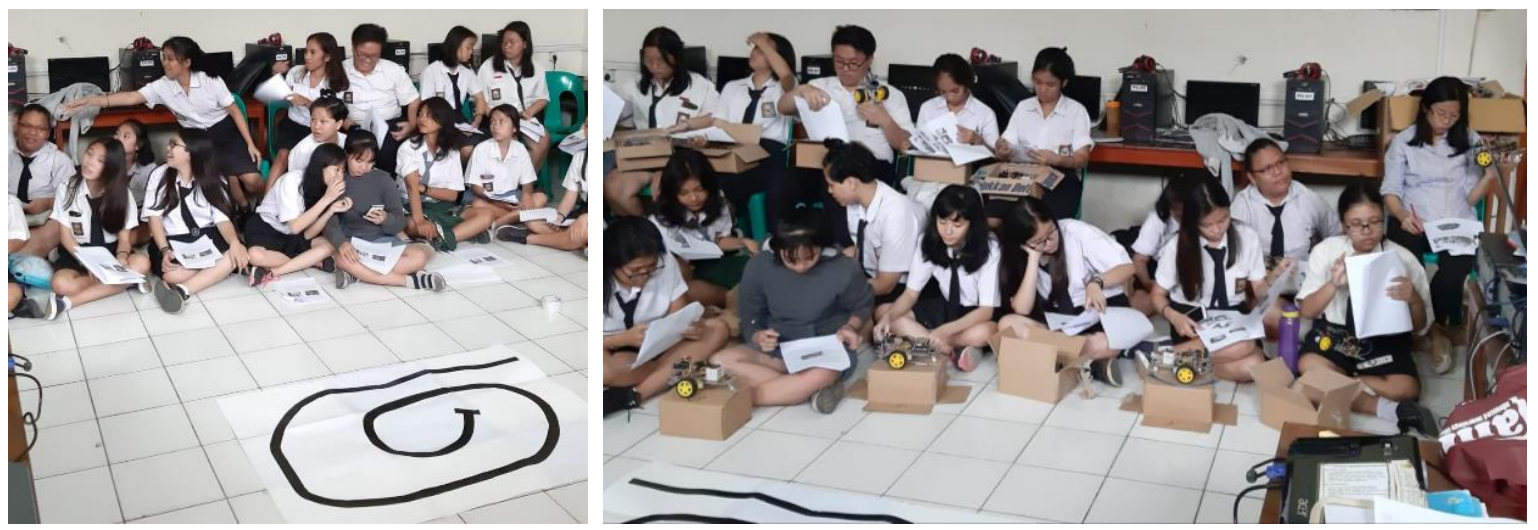

Gambar 4. Pelaksanaan Pelatihan Mikrokontroler

Dari pelatihan didapatkan bahwa peserta belum pernah melakukan pemrograman mikrokontroler sebelumnya menjadi tahu bagaimana cara memprogram mikrokontroler. Peserta juga sangat antusias dalam mengikuti kegiatan karena sudah paham pentingnya pelatihan yang diberikan melalui penjelasan dari seminar Revolusi Industri 4.0. Peserta memahami bahwa mereka harus mempersiapkan diri untuk bisa bersaing di era Industri 4.0.

Line Follower dihibahkan ke SMK Media Informatika agar selanjutnya jika ingin diajarkan ke siswa lain sudah ada alat praktikumnya. Ada juga guru yang mengikuti pelatihan sehingga selanjutnya setelah mendalami lagi guru tersebut bisa menjadi pengajar untuk pemrograman mikrokontroler.

\section{KESIMPULAN DAN SARAN}

Dari program PKM yang dibuat dalam bentuk seminar Revolusi Industri 4.0 dan dilanjutkan dengan pelatihan pemrograman Mikrokontroler didapatkan bahwa metode ini memberikan dampak lebih dibandingkan dengan hanya memberikan seminar atau pelatihan saja. Usaha dan dana yang dibutuhkan memang lebih banyak, tetapi dampak kedepannya lebih baik. Mengikutsertakan mahasiswa dalam perakitan Line Follower membuat mereka mendapatkan ilmu selain dari perkuliahan mengenai pembuatan Line Follower. Melibatkan guru dalam pelatihan memberikan kesempatan agar ilmu yang diberikan dapat diteruskan ke peserta didik lainnya.

Saran untuk kedepannya pelatihan dapat dilakukan dalam beberapa tahap dan peserta melakukan sendiri perakitan Line Follower, diakhiri dengan para peserta melombakan Line Follower yang dirakit dan diprogram. Hal ini mungkin akan lebih menarik dan peserta akan mendalami bukan hanya mikrokontroler saja, tetapi juga komponen lain pendukung mikrokontroler. 


\section{UCAPAN TERIMAKASIH}

Penulis mengucapkan terima kasih yang sebesar - besarnya kepada Institut Teknik PLN dan SMK Media Informatika Tangerang yang telah bersedia memberi dukungan dalam pelaksanaan kegiatan PKM.

\section{DAFTAR PUSTAKA}

[1] R. Drath and A. Horch, "Industrie 4.0: Hit or Hype? [Industry Forum]," IEEE Ind. Electron. Mag., vol. 8, no. 2, pp. 56-58, 2014.

[2] M. Hermann, T. Pentek, and B. Otto, "Design Principles for Industrie 4.0 Scenarios," in 2016 49th Hawaii International Conference on System Sciences (HICSS), 2016, pp. 3928-3937.

[3] M. Sitorus, J. Mangapul, H. Aziz, T. Pramono, Pawenary, and A. Gifson, "Pemrograman Mikrokontroler Guna Memperkenalkan Industri 4.0 di SMA Negeri 7 Tangerang Selatan,” J. TERANG, vol. 2, pp. 34-42, 2019.

[4] Y. Yaspin and A. Wahyu, "Pelatihan Robotik Line Follower dan Teknologi Arduino bagi Guru MIPA dan Pelajar SMA/SMK di Wilayah Kabupaten Musi Rawas," J. CEMERLANG Pengabdi. pada Masy., vol. 1, pp. 1 - 11, 2018.

[5] I. R. Sahali, F. A. Samman, R. S. Sadjad, C. Yohannes, Gassing, and A. Achmad, "Pelatihan Pengembangan Aplikasi Menggunakan Mikrokontroler untuk Meningkatkan Kompetensi Siswa SMK," J. Teknol. Terap. untuk Pengabdi. Masy., vol. 2, pp. 162-168, 2018.

[6] Z. Arifin and T. Tamrin, "Peningkatan Konmpetensi Microcontroler Siswa SMK," J. Inov. Has. Pengabdi. Masy., vol. 2, pp. 49-53, 2019.

[7] P. D. Mardika, Nilma, and R. Nuzulah, "Penyuluhan Sistem Automasi Berbasis Mikrokontroler Arduino Uno untuk Siswa-Siswi Jurusan Teknik Komputer Jaringan di SMK," J. Pengabdi. Kpd. Masy., vol. 2, pp. 148-154, 2019.

[8] H. Husada, Emillia, Y. Asri, D. Hartanti, and H. Sikumbang, "Pelatihan Aplikasi Untuk Industri Berbasis Arduino di SMK Letris Tangerang Selatan,” J. SOLMA, vol. 8, pp. 278286, 2019.

[9] Akhyar, Eliyani, Taufik, and R. Syahputra, "Pelatihan Peningkatan Skill Aplikasi Mikrokontroler Bagi Alumni Program Studi Teknologi Elektronika Jurusan Teknik Elektro Politeknik Negeri Lhokseumawe," Proceeding Semin. Nas. Politek. Negeri Lhokseumawe, vol. 3, pp. 208-210, 2019.

[10] Y. A. Badamasi, "The working principle of an Arduino," in 2014 11th International Conference on Electronics, Computer and Computation (ICECCO), 2014, pp. 1-4.

[11] M. B. Sitorus, "Kegiatan Pengabdian Pada Masyarakat Departemen Elektro IT PLN," Youtube, $2020 . \quad$ [Online]. Available: https://www.youtube.com/watch?v=1MK8U21a8Sc\&t=72s. [Accessed: 10-Jun-2020]. 